Şahin, Derya ve Gonca Gülsefa (2017). "Bursa Tophane Seramikleri”. Uludağ Üniversitesi Fen-Edebiyat Fakültesi Sosyal Bilimler Dergisi, C. 18, S. 32, s. 77-101.

\title{
BURSA TOPHANE SERAMİKLERİ
}

\author{
Derya ŞAHIN* \\ Gonca GÜLSEFA**
}

Gönderim Tarihi: Ağustos 2016

Kabul Tarihi: Kasım 2016

\section{ÖZET}

Hisar Bölgesi, geçmiş dönemlerde önemli bir yerleşim yeri olarak bilinmesine rağmen, yıllardır süre gelen yapılaşmaya maruz kalması nedeniyle oldukça tahrip edilmiştir. Değişik zaman dilimlerinde Bursa Arkeoloji Müze Müdürlügü tarafindan sondaj kazıları yapılmış ve bazı arkeolojik buluntular tespit edilmiştir. Ancak ilk defa bu kapsam dâhilinde 2015 yılında yapılan Bursa Osmangazi Belediyesinin desteği ile bölgede arkeopark yapılmak üzere Bursa Müze Müdürlü̆̈̈̈ başkanlığında, Uludă̆ Üniversitesi, Arkeoloji Bölümünün katkllarlyla sistemli alan kazıları gerçekleştirilmiştir. Kazı çalışmalarında Erken Hellenistik dönemden -Geç Osmanlı dönemine kadar yoğun miktarda seramik, lüle, sikke, cam, kemik, bronz ve demirden yapılmış objeler bulunmuştur.

Içerisinde Klasik ve Hellenistik dönemlere ait tabak/kase, günlük kullanım kapları, Hellenistik döneme ait olabilecek Kos Amphoraları, kandil, pişmiş toprak figürin, ăgırlık ve ağırşaklar vb. buluntu grubu oluşturmaktadır. Bu makalede Hisararkeopark kazılarında açmalarda bulunan seramik buluntuları seviyeler doğrultusunda incelenmiştir.

Anahtar Kelimeler: Bithynia, Hisararkeopark, seramik, lüle

* Doç. Dr., Uludağ Üniversitesi Fen-Edebiyat Fakültesi Arkeoloji Bölümü, dsahin25@hotmail.com

** Arş. Gör., Uludağ Üniversitesi Fen-Edebiyat Fakültesi Arkeoloji Bölümü, goncagulsefa@uludag.edu.tr

Uludağ Üniversitesi Fen-Edebiyat Fakültesi Sosyal Bilimler Dergisi Uludağ University Faculty of Arts and Sciences Journal of Social Sciences Cilt: 18 Sayı: 32 / Volume: 18 Issue: 32 


\section{Ceramics Find Bursa Tophane}

\section{ABSTRACT}

Hisar district, although it is known as an important settlement place in previous periods, is quite blasted because of the ongoing structuring for years. Some archeological excavations are made in several times by Bursa Archeology Museum and some archeological findings were found. But for the first time within this scope some systematic field excavations were made in 2015 with the help of Bursa Osmangazi Municipality to make an Archeopark in the area with the scholarship of Bursa Museum authority and with the contributions of Uludağ University Archeology Department. In the excavations lots of pottery, pipe, coins, glasses, bones and objects made of iron and bronze dated from Hellenistic period to late Ottoman Period were found.

Finding group includes, plates/cups dated to Hellenistic Period, daily use dishes, Kos amphoras might belong to Hellenistic Period, candles, pot figurines, weights and discs and etc. This article studied ceramic findings found in the Hisararcheopark excavations in accordance with levels.

Keywords: Bithynia, Hisararcheopark, pottery, pipe

Çalışmanın konusunu; Bursa-Tophane bölgesinde Hisar Arkeopark kapsamında yapılan arkeolojik kazılar sonucu bulunan seramikler oluşturmaktadır. İlk kez 2000 tarihinde 3. Derece sit alanı olarak tescil edilen, Hisar Bölgesinde, Bursa Arkeoloji Müdürlüğü tarafindan 2000-2004 yılları arasında çeşitli sondaj kazıları bulunmaktadır (Çiz. 1) ${ }^{1}, 2015$ tarihinde ise Bursa Osmangazi Belediyesinin desteği ile bölgede arkeopark yapılmak üzere Bursa

${ }^{1}$ Detaylı bilgi için bkz. Özkan ve Ünal 2009. Müzenin yaptığı kazı çalışmaları için lütfen inceleyin bkz. Çiz.1.

Uludağ Üniversitesi Fen-Edebiyat Fakültesi Sosyal Bilimler Dergisi Uludağ University Faculty of Arts and Sciences Journal of Social Sciences Cilt: 18 Sayı: 32 / Volume: 18 Issue: 32 
Müze Müdürlüğü başkanlığında, Uludağ Üniversitesi, Arkeoloji Bölümünün katkılarıyla sistemli alan kazıları gerçekleştirilmiştir ${ }^{2}$.

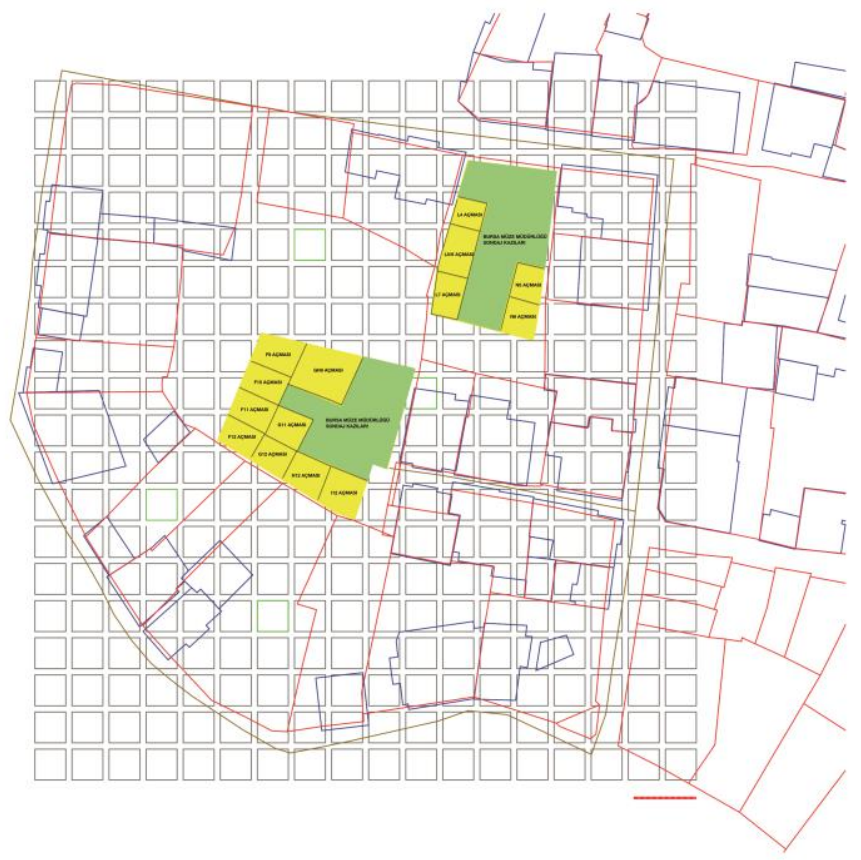

Çizim 1: Grid Sisteminde, Bursa Arkeoloji Müzesi Müdürlügünün 2000-2004 Yılları Arasında Yaptığı Çalışmalar Bir Bütün Oluşturması Amacıyla Oluşturulan Açmalar

2 Öncelikle çalışmaya bizi davet eden Bursa Arkeoloji Müze Müdürü Ali Sinan Özbey'e, alanda sorumlu müze uzmanı Hakan Bay'a teşekkür etmek istiyoruz. Bunun yanı sıra Uludağ Üniversitesi Arkeoloji Bölümünden, Araş. Gör. Gonca Gülsefa, Araş. Gör. Hazal Çıtakoğlu, Murat Akın, Semih Togan, antropolog İbrahim Semih Onur, mimar Didar Taşkan ve stajyer öğrenci olarak Fatma Selbik, Asya Karacadağ, Elif Çalık, Büşra Okumuş, Ahmet Seyda Yıldız, Orhun Kısa, Nihan Aksoy, Merve Kızılçay, Alihan Ural, Emine Özaydın yer almıştır. Katkıları için hepsine teşekkür ediyoruz. Ayrıca bazı seramiklerin sınıflandırılmasında yardımlarını bizden esirgemeyen Yrd. Doç. Dr. Filiz İnanan'a teşekkürlerimizi sunarız.

Uludağ Üniversitesi Fen-Edebiyat Fakültesi Sosyal Bilimler Dergisi Uludağ University Faculty of Arts and Sciences Journal of Social Sciences Cilt: 18 Sayı: 32 / Volume: 18 Issue: 32 
Kazı çalışmalarında amaç, tescilli binaları koruma altına aldıktan sonra, diğer riskli binaları yıkmak ve tüm bölgede arkeolojik kazılar bittikten sonra arkeopark oluşturmaktır. Bu kapsamda öncelikle, müzenin geçmiş yıllarda yapmış olduğu sondaj kazılarında temizlik çalışmaları yapılmıştır. Ardından alanda grid sistemi oluşturularak sistemli kazılara başlanmıştır ${ }^{3}$ (Çiz. 2).

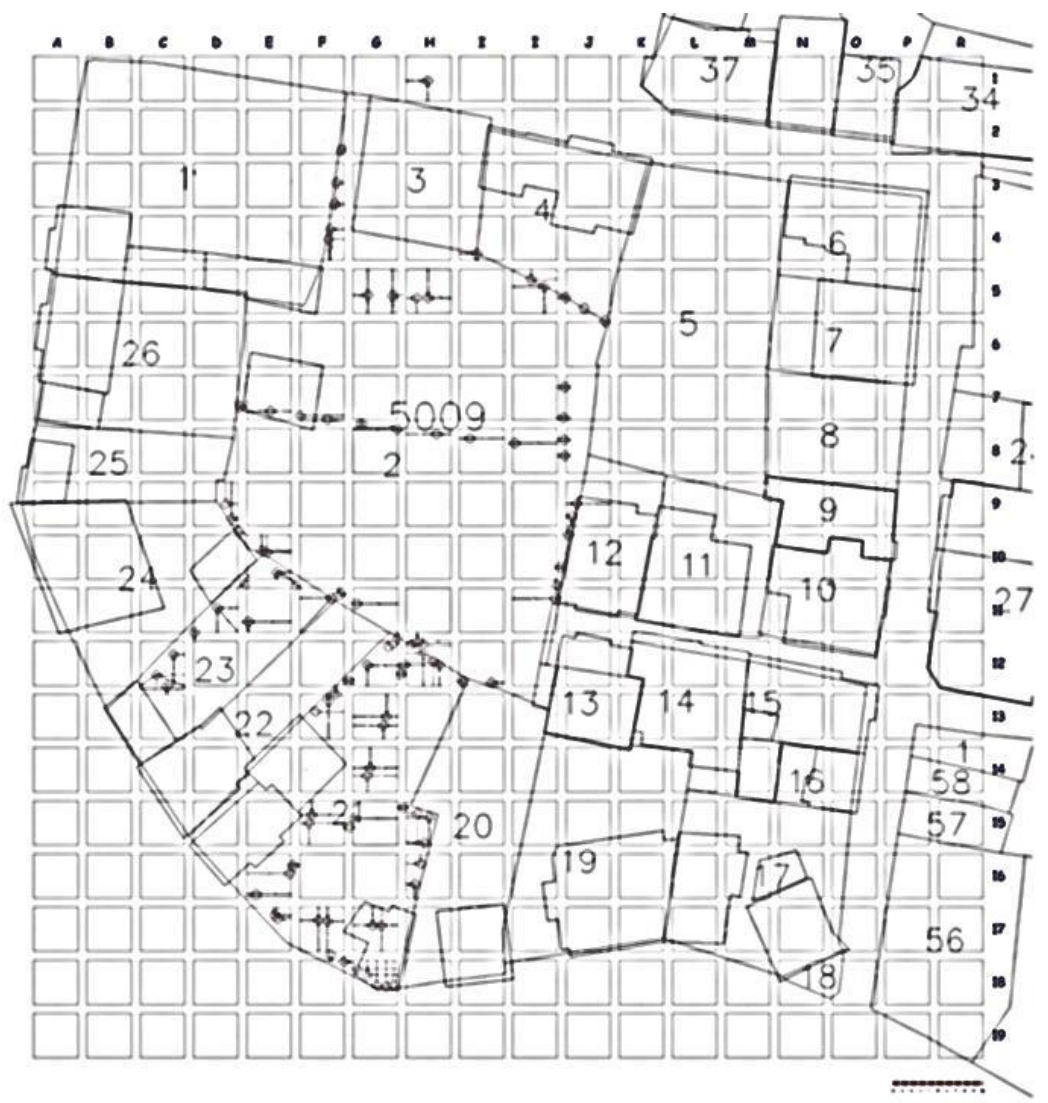

${ }^{3}$ Hisararkeopark hava fotoğrafı için bkz. Res. 1.

Uludağ Üniversitesi Fen-Edebiyat Fakültesi Sosyal Bilimler Dergisi Uludağ University Faculty of Arts and Sciences Journal of Social Sciences Cilt: 18 Sayı: 32 / Volume: 18 Issue: 32 
Çizim 2: Türkiye Ulusal Koordinat Sistemi Dikkate Alınarak Oluşturulan Grid Sistemi

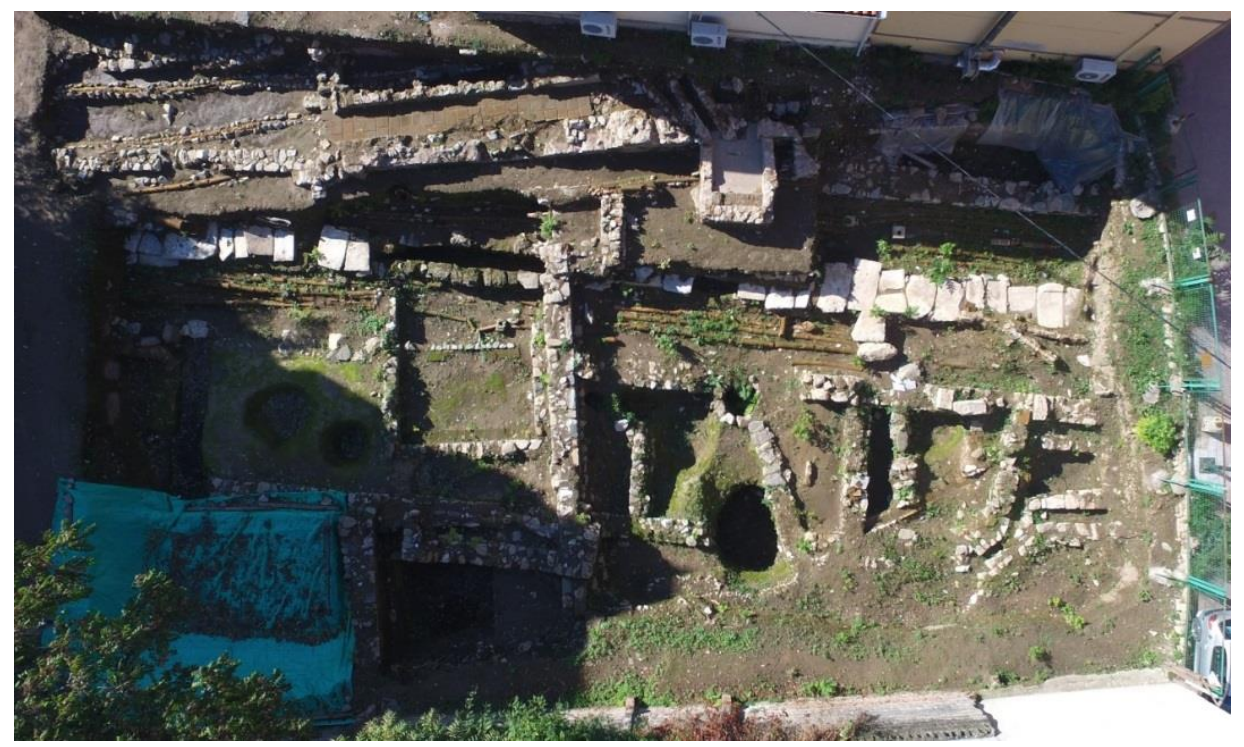

Resim 1: Hisararkeopark alanı hava fotoğrafı (Uludağ Üniversitesi, Arkeoloji Bölümü Arşivi)

Yoğun bir şekilde Osmanlı temiz su künklerinin bulunduğu alanda, Roma dönemi drenaj kanalı ${ }^{4}$, ilki 2003 yılında tespit edilerek

${ }^{4}$ Geçmiş yıllarda yapılan çalışmalarda Doğu Roma yolu olarak nitelendirilen, altından atık su kanalının geçtiği ve üzerinde $30 \mathrm{~cm}$ kalınlığında mermer bloklardan oluşturulan bir düzlem yer almaktadır. Fakat ilerleyen dönemlerde mermer düzlem işlevini yitirmiş ve üzerine çok sayıda pişmiş toprak künk sıraları yerleştirilmiştir.

Uludağ Üniversitesi Fen-Edebiyat Fakültesi Sosyal Bilimler Dergisi Uludağ University Faculty of Arts and Sciences Journal of Social Sciences

Cilt: 18 Sayı: 32 / Volume: 18 Issue: 32 
müzeye taşınan ${ }^{5}, 2015$ y1lında ise küçük bir vestibuluma ait olduğu düşünülen geometrik desenli, geç antik mozaik zemin döşemesi ( Res. 2, Çiz. 3), çok sayıda Roma, Bizans ve Osmanlı dönemlerine tarihlenen seramik ve sikke buluntusu vardır. Buluntular maalesef stratigrafi verecek nitelikte değildir, çünkü sözü edilen alan kesintisiz her dönem iskâna maruz kalmıştır.

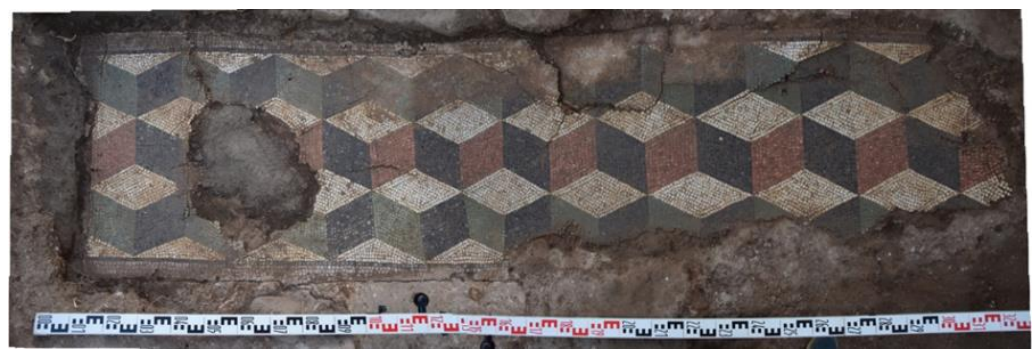

Resim 2: 340x90 cm ölçülerinde Kırmızı, Yeşil, Beyaz, Mavi ve Gri Tesseralarla Oluşturulmuş Geometrik Desenlerin Yer Aldığı Mozaik.
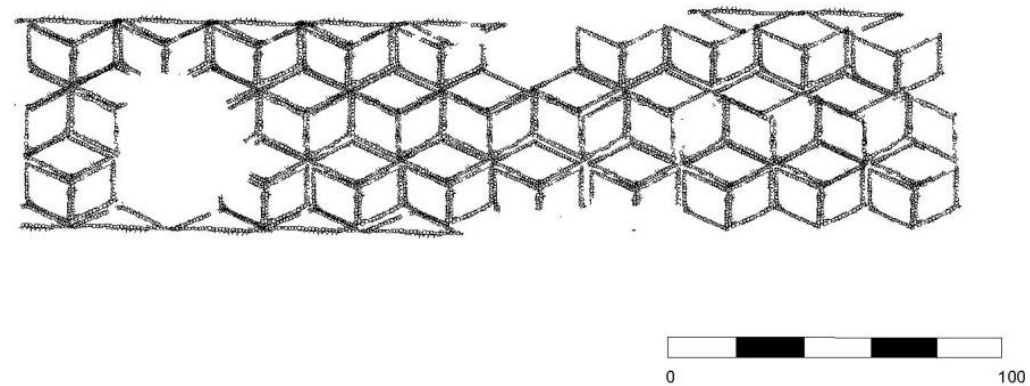

Çizim 3: Mozaiğin Çizimi.

${ }^{5} 2003$ yılında yapılan çalışmalarda alanın doğusunda $6.50 \times 4.50 \mathrm{~m}$ boyutlarında, 213 $\mathrm{cm}$ çapında üzerinde merkezde Sol ve etrafında zodyak tasviri bulunan bir mozaik döşeme bulunmuştur. Detaylı bilgi için bkz. Okçu 2009: 31 vdd.

Uludağ Üniversitesi Fen-Edebiyat Fakültesi Sosyal Bilimler Dergisi Uludağ University Faculty of Arts and Sciences Journal of Social Sciences Cilt: 18 Sayı: 32 / Volume: 18 Issue: 32 
Alanda yapılan kazı çalışmaları neticesinde 14 adet açmada çalışılmasına rağmen 9 açmadan çıkan buluntular sadece incelenmiş. Diğer 5 açmadan herhangi bir seramik buluntusu tespit edilmemiştir. Açmalarda tespit edilen buluntular aşağıdaki seviyeler doğrultusunda incelenmiştir.

\section{F 11 AÇMASI}

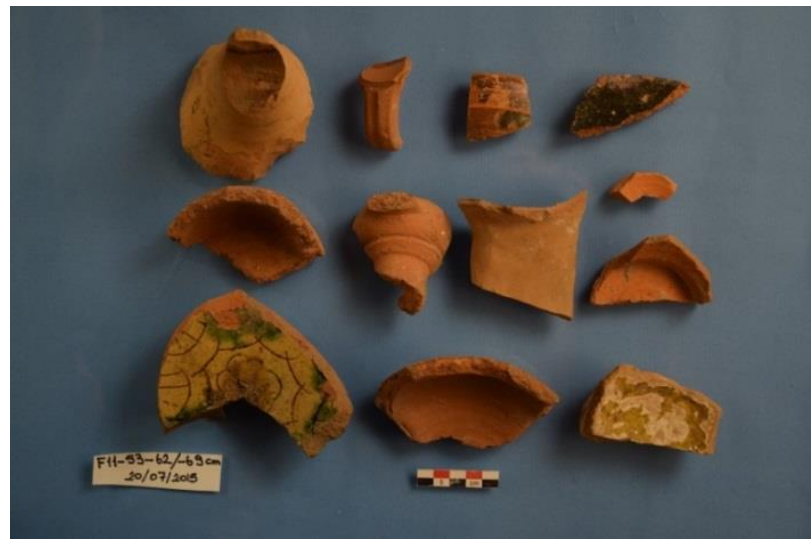

Resim 3

F 11 Açmasında Hellenistik astarlı echinus kâse ${ }^{6}$ İ.Ö. 4. yüzyıla tarihlenmektedir (Edward 1975: Plate 43.21). Ağıllıklı olarak Bizans sırlı seramikleri tek renk sırlı ya da kazıma dekorlu seramikler, Osmanlı

\footnotetext{
${ }^{6}$ Kabın formu, deniz kestanesini ve Dor başlığındaki ekhinusu anımsattığı için bu isim verilmiştir.
} 
ve İslami dönem seramikleri mevcuttur. Kazıma seramikler olarak adlandırılan hamur ve astar henüz yaşken, sivri uçlu bir aletle çizilerek veya kazınarak bezemenin yapıldığı kazıma tekniği, Yakındoğu'da İslam sanatında IX. yüzyıldan itibaren farklı dönemlerde ve bölgelerde süregelen bir teknik haline gelmiştir (Lane 1938: 33-56; Mackey 1967: 262; Amstrong 1988: 27; Özkul Findık 2014: 75). Benzer örnekler İznik Roma Tiyatrosu ve Hisararkeopark kazılarında bulunmuştur (Özkan ve Ünal 2009: 77). Ayrıca Bizans dönemine tarihlenen günlük kullanım kapları sürahi, testi parçaları tespit edilmiştir (Özkan ve Ünal 2009: 81).

$\mathrm{Bu}$ buluntuların yanı sıra alandan yoğun bir şekilde lüle buluntuları tespit edilmiştir. Buluntuların yoğunluğu Tophane bölgesinin lülecilik için önemli olduğunu bizlere sunmaktadır. Sırsız seramikler arasında sinıflandırılan lülelerin, 17. yüzyıldan itibaren Osmanlı seramikleri arasında yer almaya başlaması, tütünün ülkeye girişiyle doğru orantılıdır. Tütün haznesini içeren ve çubukluk alanından oluşan lüleler, gül ve kiraz ağaçlardan yapılan çubuklara takılmaktadır. Çubuğun diğer ucunda ise yassı bir ağızlık bulunmaktadır. Lülelerin yüzeyinde bitkisel motifler, çizgisel desenler, soyut kabartmalar mevcuttur (Uysal 2007: 554). Hisar arkeopark kazılarında çıkan lülelerin çeşitli tipte oldukları anlaşılmıştır. Bu buluntuların yüzeyinde altın yaldız kullanılmış ve üzerinde marka şeklinde mühürler bulunmaktadır (Resim 3).

Uludağ Üniversitesi Fen-Edebiyat Fakültesi Sosyal Bilimler Dergisi Uludağ University Faculty of Arts and Sciences Journal of Social Sciences Cilt: 18 Sayı: 32 / Volume: 18 Issue: 32 


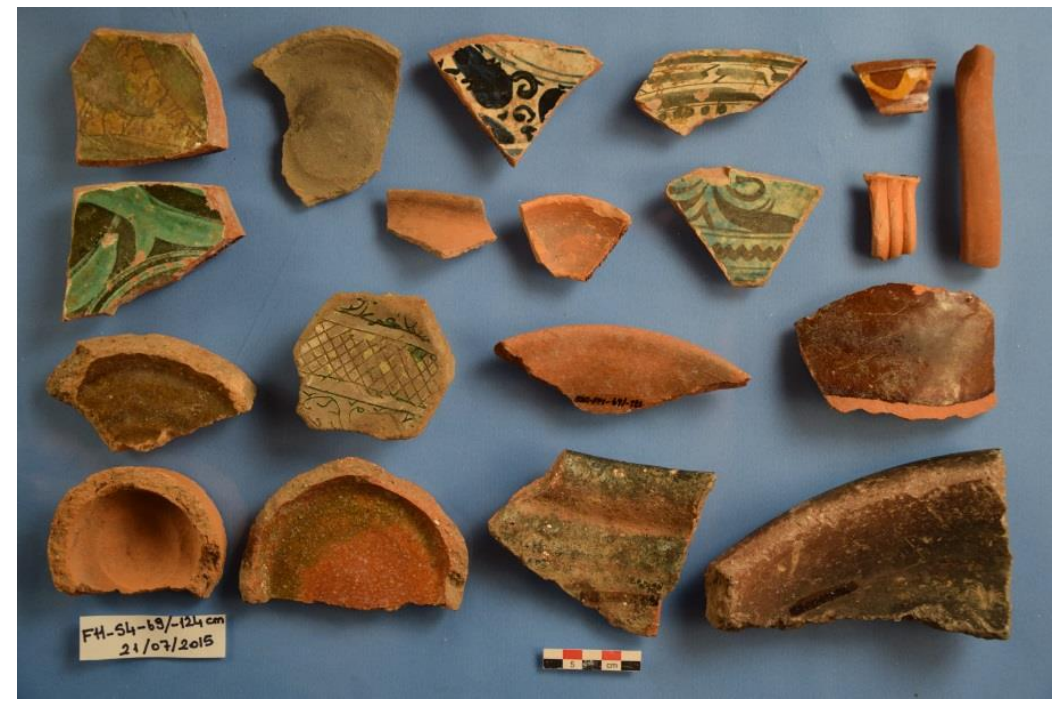

$\operatorname{Resim} 4$

F 11 Açmasında Hellenistik astarlı kâse ve açık kap formlu kap formları mevcuttur. Osmanlı dönemine ait olabilecek sırsız pişirme kabı ve testi parçaları ve "Milet İşi" Osmanlı seramikleri yoğun bir şekilde görülmektedir. 9. / 15 . yüzyıla tarihlenen kırmızı hamurlu, beyaz astarl1, mavi-beyaz renklerle bezenmiş olan bu seramikler, başlangıçta "Milet İşi”" olarak adlandırılan, ancak İznik kazıları sonrasında İznik'te üretildikleri anlaşılan grubun erken tarihli örneklerindendir. Benzer örnekler Sultan Ahmet, Türk ve İslam Eserleri Müzesinde sergilenmektedir ${ }^{7}$ (Özkan ve Ünal 2009: 97) (Resim 4).

${ }^{7}$ Ayrıntılı bilgi için bkz. http://www.explorewithmwnf.net/ (Erişim: 07.04.2016)

Uludağ Üniversitesi Fen-Edebiyat Fakültesi Sosyal Bilimler Dergisi Uludağ University Faculty of Arts and Sciences Journal of Social Sciences Cilt: 18 Sayı: 32 / Volume: 18 Issue: 32 


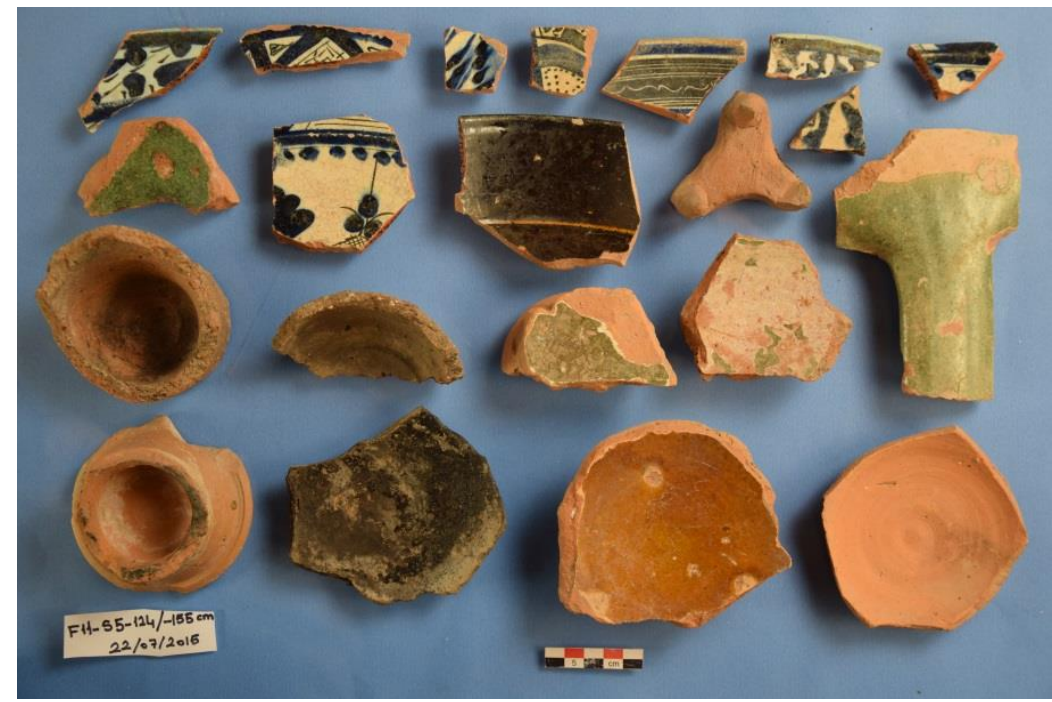

Resim 5

Osmanlı dönemine ait olabilecek sırsız pişirme kabı ve testi parçaları, Milet işi Osmanlı seramikleri yoğun bir şekilde görülmektedir. Bu seramikler üzerinde geometrik ve bitkisel motifler yer almaktadır. Benzer örnekler Pergamon kazılarında bulunmuştur (Mania 2006: 487). Ayrıca seramiklerin pişirilmesinde yardımcı eleman olarak kullanılan 1 adet üçayak, ele geçen buluntular arasındadır. Benzer örnekler Milet (Böhlendorf Arslan, 2008: 388) ve Pergamon kazılarında (Mania 2006: 490) bulunmuştur. Bu da bize Tophane Bölgesinde seramik üretimiyle ilgili önemli veriler sunmaktadır (Çakmakçı ve İnanan 2009: 67; Res. 1-2; Özkan ve Ünal 2009: 79; Waksman 2014: Fig. 8) (Resim 5). 


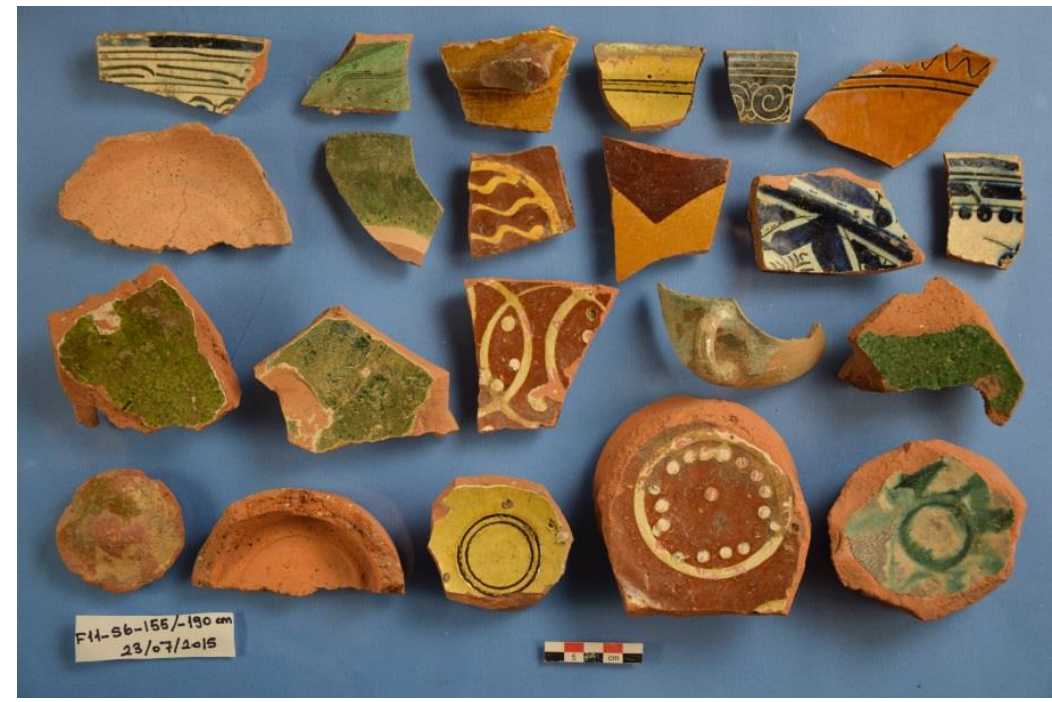

Resim 6

Buluntular içindeki Bizans dönemi seramiklerinin tümü kırmızı hamurludur ve iki ana grupta toplanmaktadırlar. Bunlardan biri "Zeuksippus Ailesi" olarak tanınan grup (Özkul Fındık 2014: 77), bir diğeri ise Bizans dönemi "Sgraffito Kapları" olarak sinıflandırabileceğimiz örneklerdir. "Zeuksippus Ailesi" olarak bilinen seramik tipleri Anadolu ve dişındaki, dönemin en önemli seramiklerinden biridir (İnanan, 2014: 1). 12.yüzyıl sonu ile 13. yüzy1la tarihlendirilen Zeuksippus Ailesi seramik buluntularına ait parçaların, sadece tek renk sarı sırlı kaide ve amorf gövde parçaları ile sınırlı kalması hayli ilginçtir. Bu örneklerde grubun karakteristik Zeuksippus seramiklerinde merkezde boş daire ya da içinde palmet, rumi, çiçek ve helezonlar yer almaktadır (Özkul Findık 2014: 77). Benzer örnekler Nilüfer ili yüzey araştırmalarında tespit edilmiştir (İnanan 2016: Tablo 1-Kat no: 2, 3,4, 5.6.7, Tablo 2-Kat. no: 18,19, Tablo 3-Kat. no. 25, 36). Bizans döneminin en popüler bezeme tekniği olan sgraffito 
dekorasyonlu birkaç amorf gövde parçası da buluntular arasındadır (Özkul Fındık 2014: 77) (Resim 6).

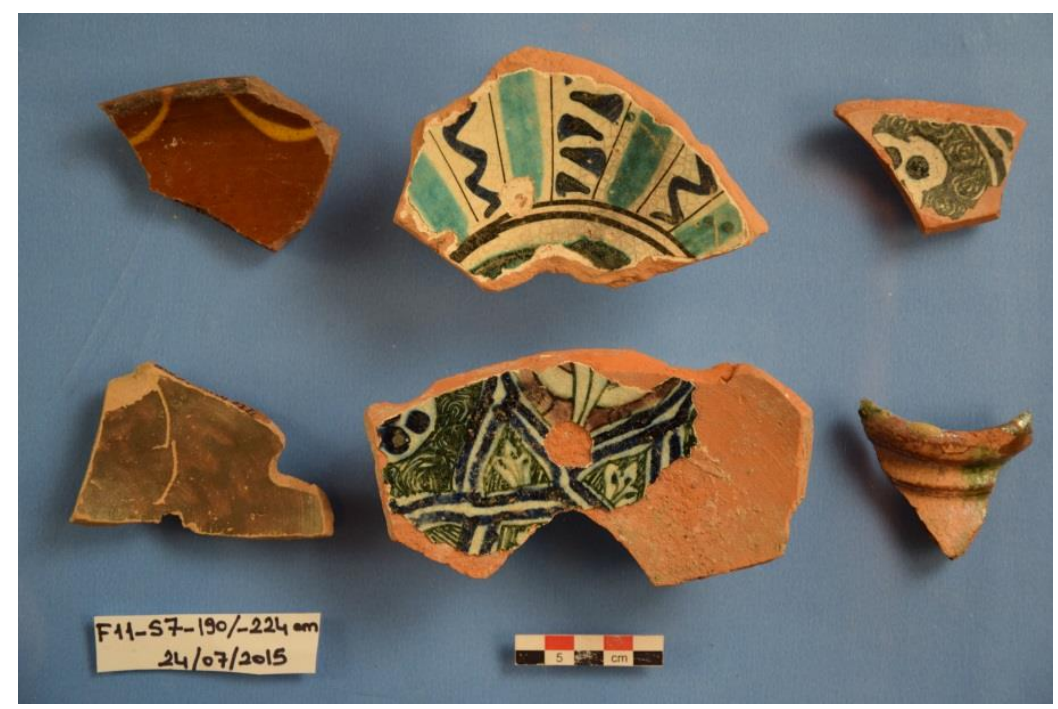

Resim 7

Hellenistik siyah astarlı kap parçaları, M.Ö. 4. yüzyıla tarihlenmektedir (Edward 1975: Plate 43.21). M.Ö. 4. yüzyıla tarihlenen Hellenistik Astarlı kap parçaları bölge yakınlarında diğer buluntu yerlerinden de bilinmektedir (Şahin 2017: no. 1,2; Gülsefa ve Çıtakoğlu 2017: 308: no.3-4). Zeuksippos Ailesi'ne ait olabilecek seramiklerde yoğun olarak ele geçen seramik tipleri arasında yer almaktadır (İnanan 2014: 1). Milet İşi seramikleri de yoğun olarak görülmektedir. Benzer seramikler İznik Roma tiyatro kazılarında bulunmuştur (Özkul 1999: 551-554) (Resim 7).

Uludağ Üniversitesi Fen-Edebiyat Fakültesi Sosyal Bilimler Dergisi Uludağ University Faculty of Arts and Sciences Journal of Social Sciences

Cilt: 18 Sayı: 32 / Volume: 18 Issue: 32 


\section{G 11 AÇMASI}

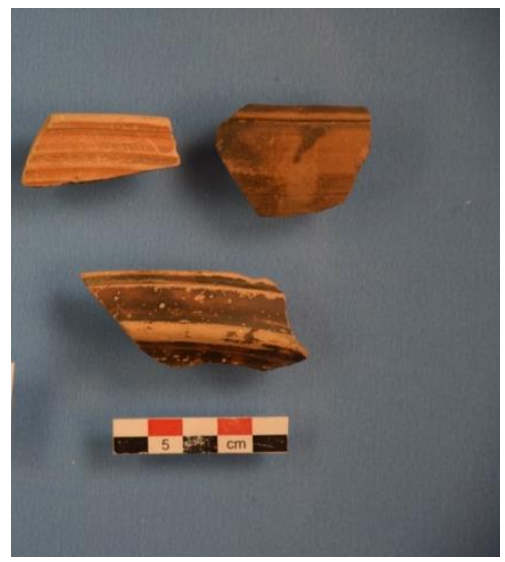

Resim 8

Hellenistik astarlı tabak, kâse ve çeşitli açık kap formları ele geçen buluntular arasında yer almaktadır. Benzer örnekler Aizanoi (Ateş 2003: Taf. 80,1), Magarsos (Şahin 2014: 147 vd, 157 vd. no. 930) ve Bergama (Schaefer 1968: lev. 1-4), gibi Küçük Asya'da farklı bölgelerdeki buluntu yerlerinden de belgelenmişlerdir. Buluntu özelliklerine bakılırsa seramikler İ.Ö. 4. yüzyıla tarihlenmektedir (Resim 8). 


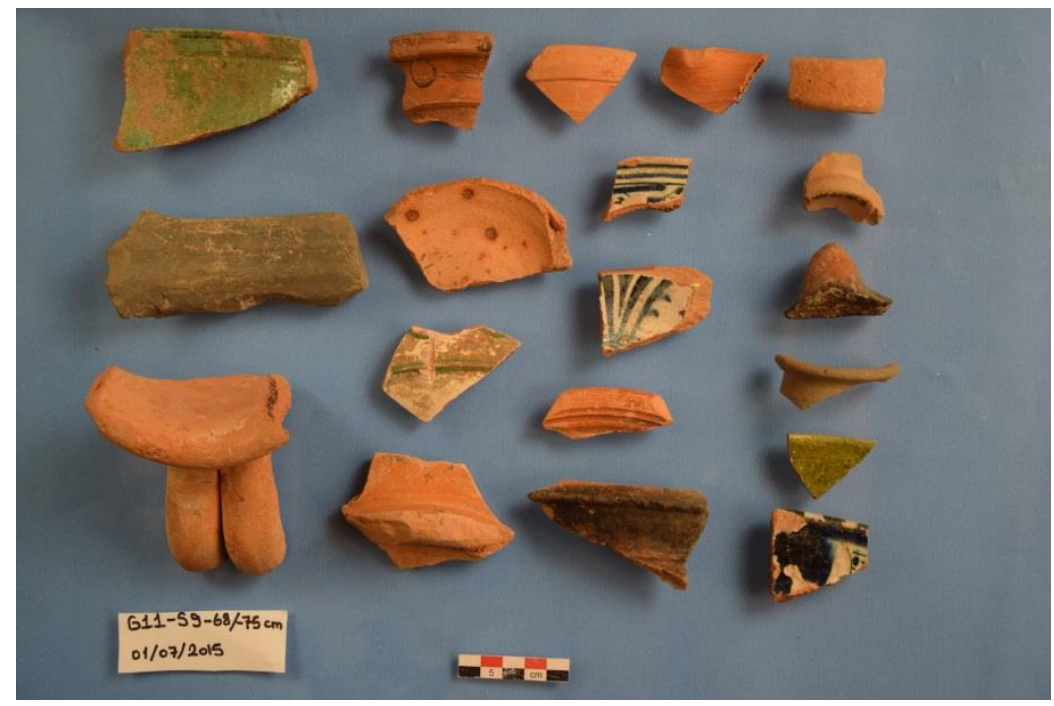

Resim 9

Hellenistik astarlı kâse ya da tabak formlu kaplar, oinoche ve çeşitli dönemi tam olarak tespit edilemeyen sürahi/testi formlu parçalar mevcuttur Hellenistik dönem dünyasında kahverengi, kırmızımsı kaplar yoğun bir şekilde ele geçen buluntular olarak bilinmektedir (Körsulu, 2014: 93; fig. 7-7a). Bu buluntuların yanı sira Kos amphorasina ait olabilecek kulp parçası tespit edilmiştir. Antik Çağ'da amphoralar gemilerde zeytin, zeytinyağı şarap, tahıl gibi malzemelerin taşınmasında ticaret açısından önemli kaplar olarak bilinmektedir. Kos amphoraları ise çift kulp karakteristik bir özellik olarak bilinmektedir (Doğer 1990:7; Şenol 2003: III; Şenol 2009: 7) (Resim 9). 


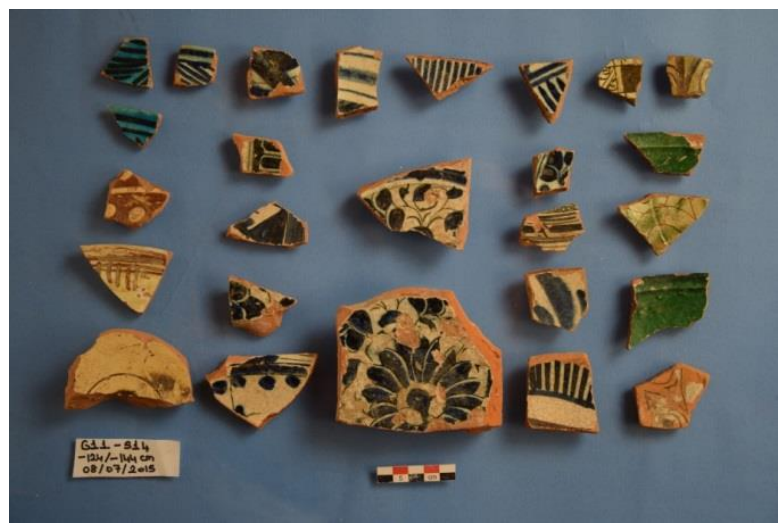

Resim 10

Bizans seramik buluntuları içerisinde Zeuksippus Ailesi I. tipe ait olabilecek örnekler mevcuttur. Seramiklerin yüzeyinde daire ve şerit motifleri dikkat çekmektedir (Özkul Fındık 2014: 165; Fotoğraf 5). Diğer bir buluntu grubunu ise Beylikler dönemine ait olabilecek tek renk sırlı kaplar oluşturmaktadır (Gürhan Gök 2008: 66). Hisararkeopark kazılarında ise koyu yeşil, tek renk sırlı kap parçaları ele geçen buluntular arasındadır. Tek renk sırlı kaplar olarak adlandırılan bu kaplar XIV. yüzyıl ile XV. yüzyılın başlarına tarihlenmektedir (Gürhan Gök 2008: 77; Tablo 4: Kat No. 2). Selçuklular dönemine ait olan Sıraltı Tekniği ile yapılmış sırlı turkuaz kâse Kubad-Abad, Büyük Saray'da seramik koleksiyonları içerisinde yer almaktadır ${ }^{8}$ (Arık 2007: 495; fig. 8-9). Kubad-Abad kazılarında ele geçen sıraltı tekniğinde süslenmiş bir grup buluntu, boyutlarının küçüklügü; geometrik ve soyut bitkisel motifler, yazı ve Uygur tipli figürlerden oluşan kompozisyon zenginliğiyle, Selçuklu çiniciliği için yeni bilgiler sunmaktadır (Arık 2007: 490). Ayrıca diğer açmalarda da

8 http://www.anadoluselcuklumimarisi.com/selcuklular/selcuklu-el-sanati/seramiksanati (Erişim: 05.05.2016)

Uludağ Üniversitesi Fen-Edebiyat Fakültesi Sosyal Bilimler Dergisi Uludağ University Faculty of Arts and Sciences Journal of Social Sciences Cilt: 18 Sayı: 32 / Volume: 18 Issue: 32 
Milet işi seramikleri de yoğun olarak görülmektedir. Ayrıca lüleler de buluntular arasinda yer almaktadır (Resim 10).

\section{G 12 AÇMASI}

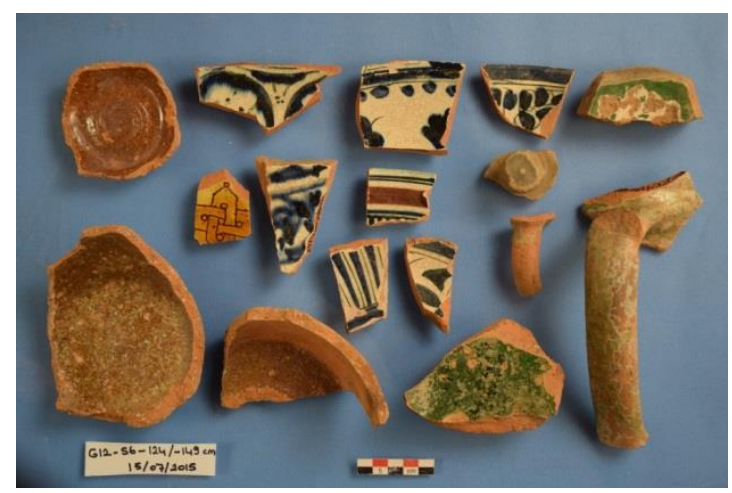

Resim 11

Beylikler dönemine ait olabilecek tek renk sırlı tabak/kase, sürahi/testi kap formları arasında yer almaktadır (Gürhan Gök 2008: 66). Diğer bir buluntu grubunu ise Milet işi seramikleri oluşturmaktadır. $\mathrm{Bu}$ seramiklerin üzerinde bitkisel motifler, düz şeritler mevcuttur (Özkan ve Ünal 2009: 97). Ayrıca lüleler de buluntular arasında yer almaktadır (Resim 11). 


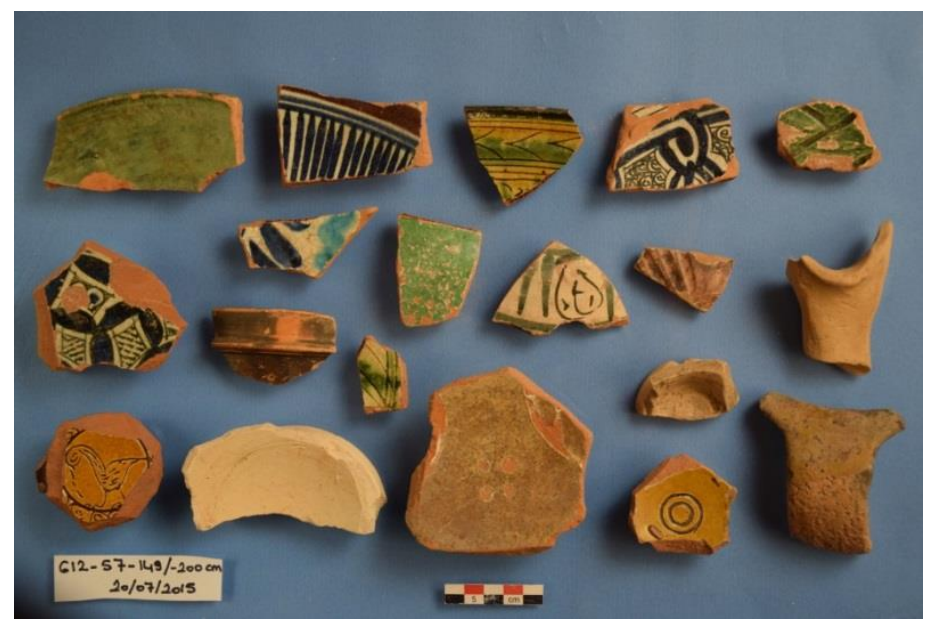

Resim 12

Klasik/Hellenistik dönem tabak/kase, Geç Roma-Bizans dönemlerine tarihlenebilecek sürahi/testi ve pişirme kapları içerisinde ise tencere formlu kap parçaları ele geçen seramik buluntular arasındadır. Benzer örneklere Zeugma Kazıları'nda rastlanılmıştır (Reynal Abadie vd., 2007: 186-187). Bizans seramik buluntuları içerisinde Zeuksippus Ailesi I. tipe ait olabilecek örnekler mevcuttur. Motif olarak ise daire ve şerit motifleri dikkati çekmektedir. Benzer örnekler Smyrna Agorası Kazıları'nda bulunmuştur (Özkul Fındık 2014: 165; Fotoğraf 5). Bu motiflerin dışında daire içerisinde rumi, kuş, monogram, çiçek rozet motifleri görülmektedir (Özkul Fındık 2014: 81). Hisararkeopark kazılarında ise koyu yeşil, tek renk sırlı seramik parçaları tespit edilmiştir. Tek renk sırlı kaplar olarak adlandırılan bu örnekler XIV. yüzyıl ile XV. yüzyılın başlarına tarihlenmektedir (Gürhan Gök 2008: 77; Tablo 4: Kat No. 2). Ayrıca diğer açmalarda da görülen Osmanlı dönemine ait Milet işi seramikleri de yoğun olarak görülmektedir (Özkan ve Ünal 2009: 97) (Resim 12). 


\section{H 12 AÇMASI}

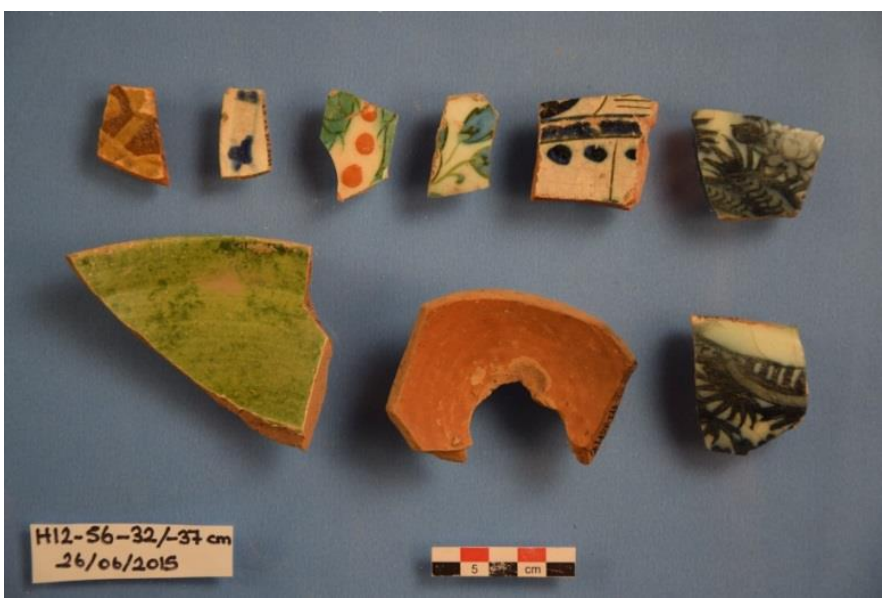

Resim 13

Diğer açmalarda olduğu gibi Klasik/Hellenistik döneme ait olabilecek seramik parçaları mevcuttur. Ayrıca Osmanlı dönemine ait Milet işi seramikleri de yoğun olarak görülmektedir. Koyu yeşil, tek renk sırlı kap parçası tespit edilmiştir. Tek renk sırlı kaplar ise XIV. yüzyıl ile XV. yüzyılın başlarına tarihlenmektedir (Gürhan Gök 2008: 77; Tablo 4: Kat No. 2). Üzerinde bitkisel motiflerin yer aldığı İznik seramikleri buluntular arasındadır. Bu tür seramikler Osmanlı dönemi için önemli bir yere sahiptir. (Arthur 2007: 249: Fig. 3-4-5) (Resim 13).

\section{12 AÇMASI}




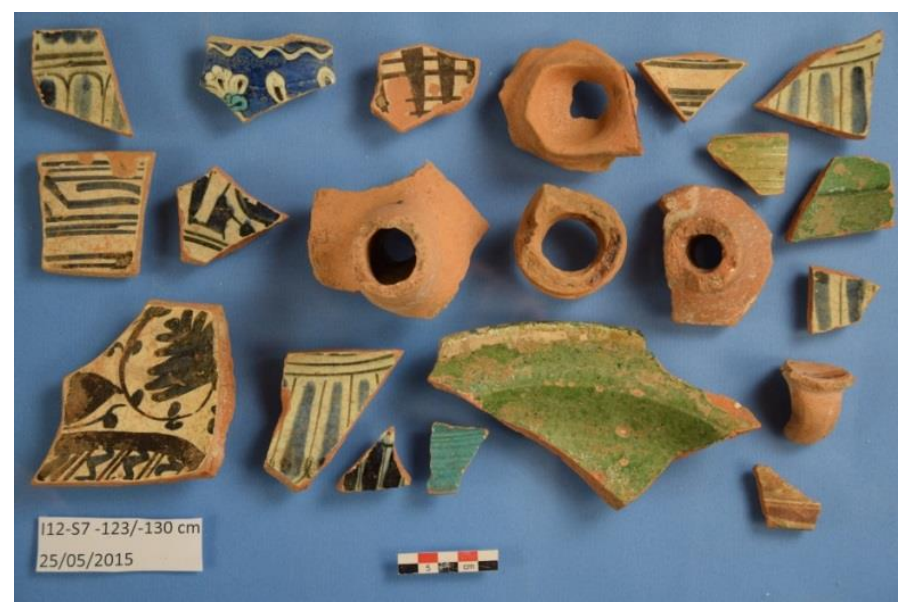

Resim 14

Beylikler dönemine ait tek renk sırlı kaplar oluşturmaktadır (Gürhan Gök 2008: 66). Diğer bir buluntu grubunu ise Milet işi seramikleri oluşturmaktadır. Bu seramiklerin üzerinde bitkisel motifler, düz şeritler mevcuttur. Ayrıca lüleler de buluntular arasında yer almaktadır (Resim 14).

\section{4 AÇMASI}

Uludağ Üniversitesi Fen-Edebiyat Fakültesi Sosyal Bilimler Dergisi Uludağ University Faculty of Arts and Sciences Journal of Social Sciences

Cilt: 18 Sayı: 32 / Volume: 18 Issue: 32 


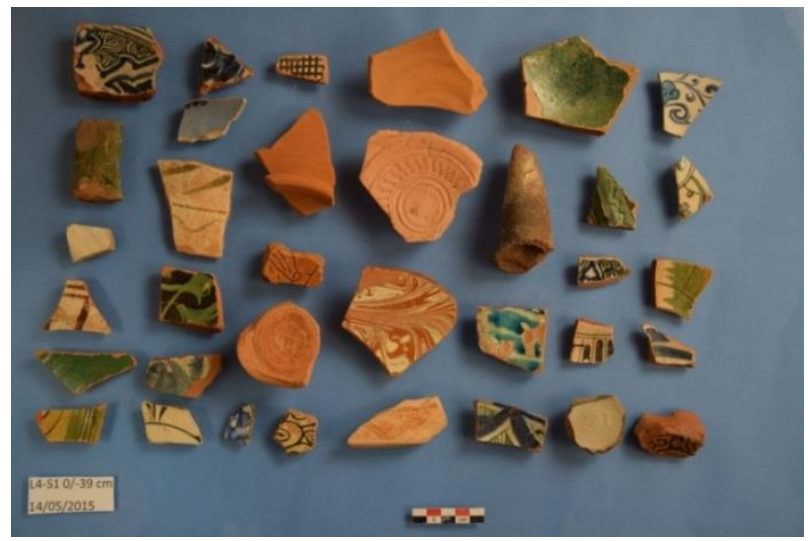

Resim 15

Klasik döneme ait olabilecek tabak parçaları, tek renk sırlı Beylikler dönemine ait tabak/kase parçaları, Osmanlı dönemine ait tek sır astarlı yeşil sürahi/testi'ye ait emzik ağızlı günlük kullanım kapları, lüleler (Resim 16-17) ve bunun yanı sıra mermer dekorlu seramikler de ele geçen buluntular arasındadır. Mermer dekorlu kaplar İtalya üretimi seramikler arasında değerlendirilmektedir. Bu teknikte kaliteli, sert ve kırmızı hamurlu seramik üzerine, sıvı renkli astar /sır ebru deseni oluşturacak şekilde karıştırılarak uygulanmaktadır. $\mathrm{Bu}$ desen ise mermer dekorunu anımsattığı için bu isim verilmiş̧ir (Gök 2011: 67) (Resim 15).

Resim 16

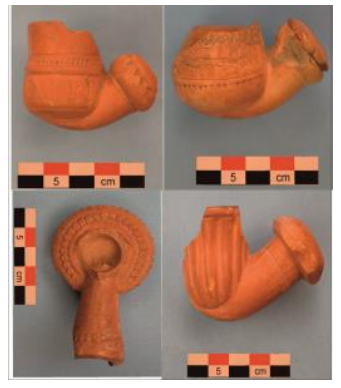

Uludağ Üniversitesi Fen-Edebiyat Fakültesi Sosyal Bilimler Dergisi Uludağ University Faculty of Arts and Sciences Journal of Social Sciences

Cilt: 18 Sayı: 32 / Volume: 18 Issue: 32 

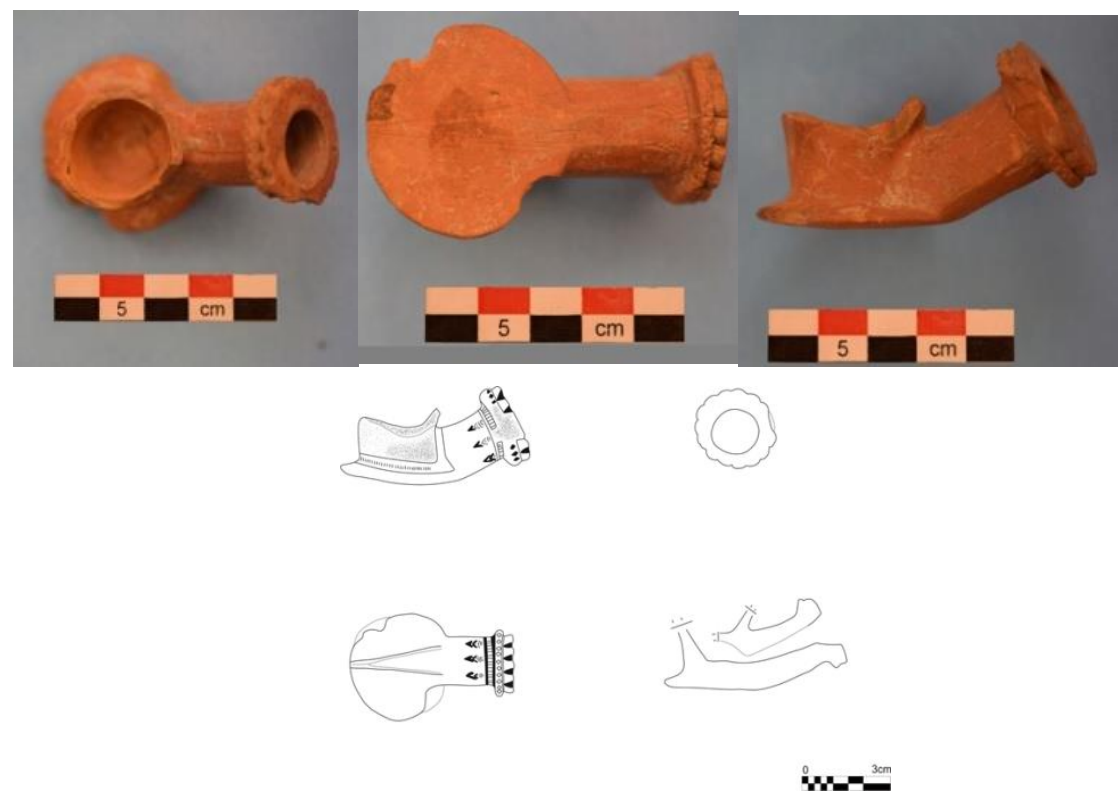

Resim 17

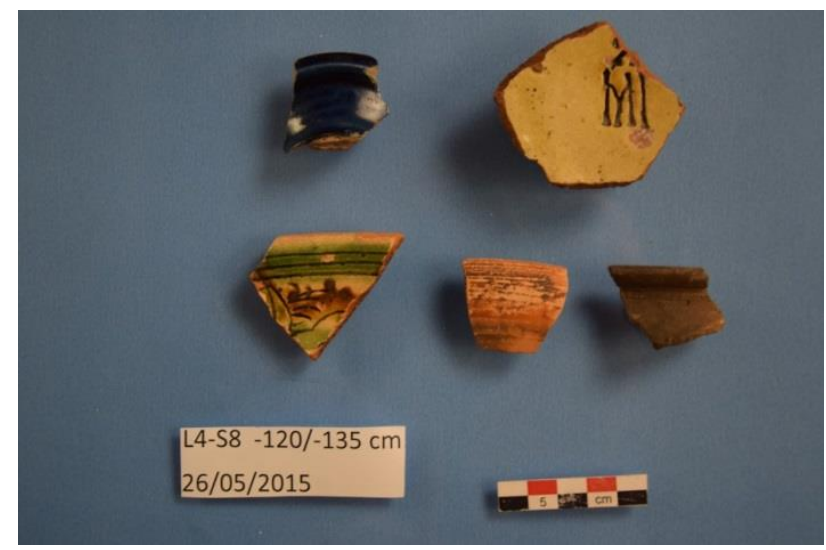

Uludağ Üniversitesi Fen-Edebiyat Fakültesi Sosyal Bilimler Dergisi Uludağ University Faculty of Arts and Sciences Journal of Social Sciences Cilt: 18 Sayı: 32 / Volume: 18 Issue: 32 
Resim 18

Bizans seramik buluntuları içerisinde Zeuksippus Ailesi I. tipe ait olabilecek örnekler mevcuttur. Monogram motifi dikkati çekmektedir (Özkul Fındık 2014: 165; Fotoğraf 5) (Resim 18).

\section{L5-L6 AÇMASI}

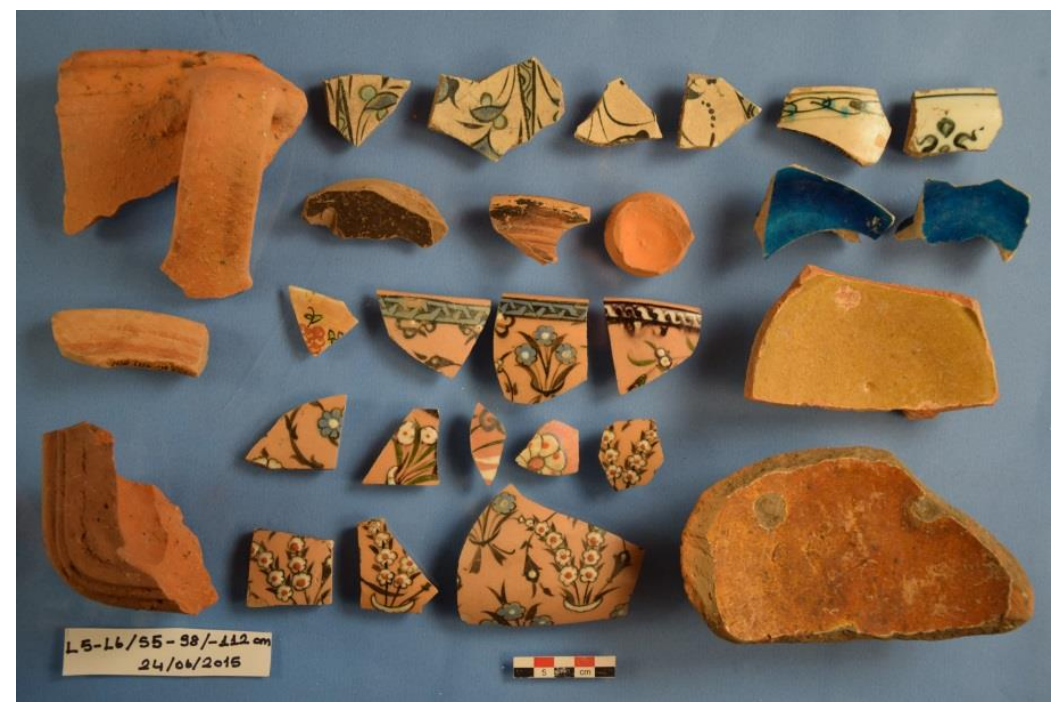

Resim 19

Osmanlı dönemine ait İznik üretimi olduğu düşünülen bitkisel desenli kase, tek renk sırlı Bizans seramikleri ele geçen buluntular arasindadir (Resim 19).

Uludağ Üniversitesi Fen-Edebiyat Fakültesi Sosyal Bilimler Dergisi Uludağ University Faculty of Arts and Sciences Journal of Social Sciences

Cilt: 18 Sayl: 32 / Volume: 18 Issue: 32 


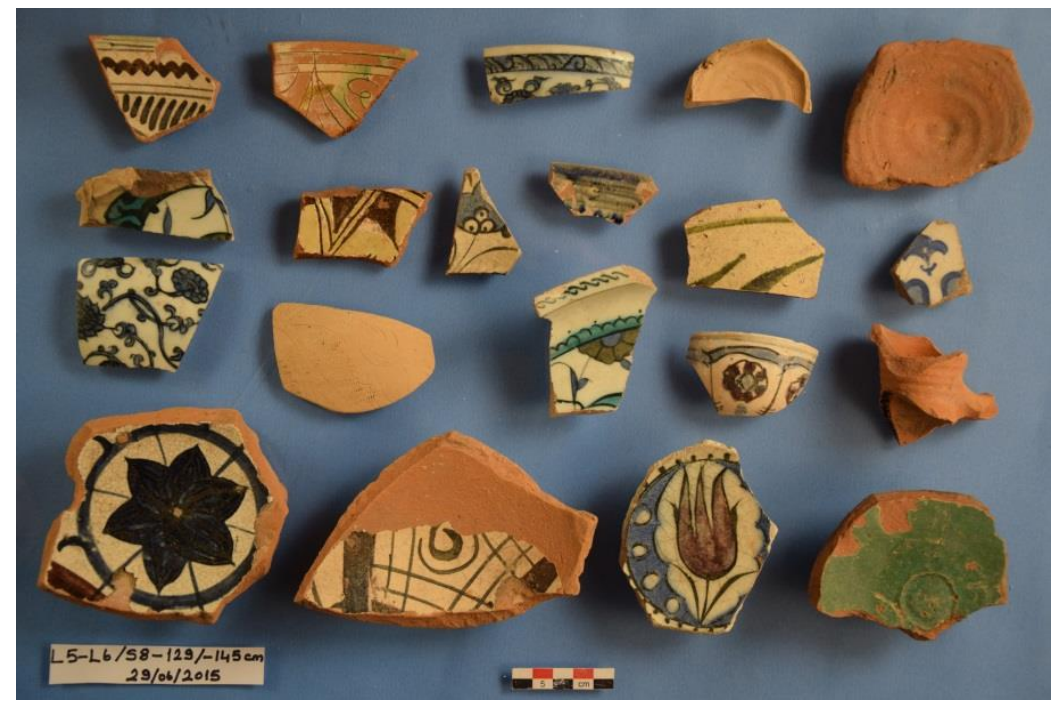

Resim 20

Osmanlı dönemine ait yeşil tek sırlı kaplar ve Milet işi seramikler buluntular içerisinde yer almaktadır (Özkul 1999: 551-554). Yine Osmanlı dönemine ait olabilecek üzerinde lale, çiçek, sarmaşık motiflerinin olduğu kaplar da dikkati çekmektedir (Resim 20).

\section{7 AÇMASI}

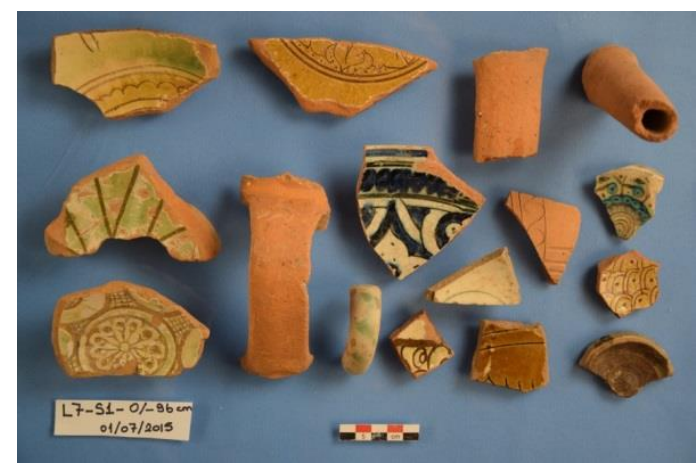

Resim 21

Uludağ Üniversitesi Fen-Edebiyat Fakültesi Sosyal Bilimler Dergisi Uludağ University Faculty of Arts and Sciences Journal of Social Sciences Cilt: 18 Sayı: 32 / Volume: 18 Issue: 32 
Bizans döneminin en popüler bezeme tekniği olan sgraffito dekorasyonlu birkaç amorf gövde parçası da buluntular arasındadır (Özkul Fındık 2014: 77). Osmanlı dönemine ait sürahi/ testi, emzik ağızlı günlük kullanım kapları ele geçen buluntular arasında yer almaktadır. Diğer bir buluntu grubunu ise Milet işi seramikleri oluşturmaktadır. Bu seramiklerin üzerinde bitkisel motifler, düz şeritler mevcuttur (Özkul 1999: 551-554) (Resim 21).

\section{DEĞERLENDİRME ve SONUÇ}

Hisar bölgesinde yıllardır gelen yapılaşmadan dolayı yoğun bir tahribat söz konusudur. Erken Hellenistik dönemden -Geç Osmanl1 dönemine kadar çok sayıda seramik, sikke, cam, kemik, bronz ve demirden yapılmış objeler bulunmuştur. Bunların yanısıra mimari buluntular da tespit edilen buluntular arasındadır. Klasik ve Hellenistik dönemlere ait tabak/kâse, günlük kullanım kapları, Hellenistik döneme ait olabilecek Kos Amphoraları, kandil, pişmiş toprak figürin, ağırlık ve ağırşaklar vb. buluntu grubunu oluşturmaktadır.

9-15. yüzyıllar arasına tarihlendirilen Milet işi Osmanlı seramikleri yoğun olarak görülmektedir. Kırmızı hamurlu gruplarda Ege kapları olarak tanımlanan ince sgraffito, kazıma, astar boyama, çok renkli kazıma, Zeuksippos seramik buluntuları, Selçuklular dönemine ait olan Sıraltı tekniği ile yapılmış sırlı turkuaz kâse ve Beylikler dönemine ait olabilecek tek renk sırlı kaplar, İtalya üretimi olarak bilinen mermer dekorlu seramikler ele geçen buluntular arasındadır.

Bununla birlikte çeşitli saklama, taşıma ve mutfak kapları da ele geçen buluntular arasındadır. Osmanlı dönemine ait farklı tiplerdeki lüleler ise yoğun bir şekilde bulunmuştur. Buluntuların yoğunluğu Tophane bölgesinin lülecilik için önemli olduğunu bizlere sunmaktadır. Osmanlı dönemine ait İznik üretimi olduğu düşünülen bitkisel desenler 
buluntular arasındadır. Önemli buluntular arasında seramik firınlamayla ilgili üçayaklar yoğun olarak ele geçen buluntular arasındadır.

\section{KAYNAKLAR}

Arık, Rüçhan (2007). “Anadolu Selçuklu Saraylarında Çini” Anadolu Toprağının Hazinesi Çini Selçuklu ve Beylikler Çağı Çinileri. İstanbul: T.C. Kültür Bakanlığı Yayınları, s. 219-399.

Armstrong, Pamela (1993). "Byzantine Thebes: Excavation on the Kadmeia 1980". BSA, 88, s. 295-335.

Arthur, Paul (2007). "Byzantine and Turkish Glazed Ceramics in Southern Apulia". Italy, Byzas 7 - Late Antique and Medieval Pottery and Tiles in Mediterranean Archaeological Contexts BohlendorfArslan, Beate - A.O. Uysal - J. Witte-Orr (eds.), İstanbul: Ege Yayınları, s. 239-254.

Ateş, Güler (2003). "Rote Feinkeramik von Aizanoi als lokaler Kulturträger". (Danışman: Prof. Dr. Tonio Hölscher), Ruprecht-KarlsUnıversität Heidelberg, Heidelberg.

Böhlendorf Arslan, Beate (2008). "Keramikproduktion im Byzantinischen und Türkischen Milet". ISTMITT 58: Tübingen, Verlag Ernst Wasmuth, s. 371-407.

Doğer, Ersin (1990). Antik Çağda Amphoralar, İzmir: Sergi Yayınevi.

Edwards, G. Roger (1975). Corinth VII.3. "Corinthian Hellenistic Pottery". Vol.7.3, Athens, American School of Classical Studies at Athens.

Gök, Sevinç (2008). "Beylikler Dönemi'ne ait Sgraffito Teknikli ve Tek Renk Sirlı Kaplar (Manisa Gülgün Hatun Hamamı Buluntuları)". Sanat Tarihi Dergisi, S: XVII/2, Ekim, s. 59-83. 
Gök, Sevinç (2011). "Akdeniz Ticaretinin Önemli Bulgu Buluntuları: Seramikler". Sanat Tarihi Dergisi, C. XX, S: 2, Ekim, s. 61-100.

Gülsefa, Gonca ve Hazal Çıtakoğlu (2017 baskıda). "2015 Yı1ı Bursa Nilüfer Yüzey Araştırmasında Tespit Edilen Klasik, Hellenistik ve Roma Dönemi Seramikleri”. Odrysses'ten Nilüfer'e Uluslararası Nilüfer Sempozyumu, Bursa: Özyurt Matbaac1lık, s. 305-332.

İnanan, Filiz (2014). "Zeuksippus Tipi Seramiklerin Anadolu'daki Dağılımları”. Uludağ Üniversitesi Fen-Edebiyat Fakültesi Sosyal Bilimler Dergisi C. 15, S. 26, s. 149-166.

(2016). "Nilüfer ve Mahalleleri Yüzey Araştırmalarında Ele Geçen Bizans ve Osmanlı Dönemi Seramik Buluntuları". Odrysses'ten Nilüfer'e Uluslararası Nilüfer Sempozyumu, Bursa: Özyurt Matbaacılık, s. 359-382.

İnanan, Filiz ve Zeynep Oral Çakmakçı, (2009). "Ortaçağ Bizans Günlük Yasamı ve Üretim Faaliyetleri Açısından Kuşadası Kadıkalesi Buluntuları". Ege Üniversitesi Sanat Tarihi Dergisi, S. XVIII/1, Nisan, s. $51-72$.

Körsulu, Hatice (2014). Kappadokia Komana'sl Hellenistik Dönem Seramikleri, Cedrus II: Antalya: Sadri Grafik Matbaac1lık, s. 89-133.

Lane, Arthur (1938). "The Early Sgraffito Ware of the Near East". Transactions of the Oriental Ceramic Society, s. 33-56.

Mackay, T. S. (1967). "More Byzantine and Frankish Pottery from Corint". Hesperia 3: Athens, American School of Classical Studies at Athens, s. 250-330.

Mania, Ulrich (2006). Mania, Eine Neue Werkstatt Früher Türkischer Keramik-Miletware aus Pergamon, ISTMITT 56: Tübingen, Verlag Ernst Wasmuth, s.475-501.

Okçu, Recep (2009). "Prusia ad Olympum Mozaikleri". JMR 3: İstanbul: Ege Yayınları, s. 31-51.

Uludağ Üniversitesi Fen-Edebiyat Fakültesi Sosyal Bilimler Dergisi Uludağ University Faculty of Arts and Sciences Journal of Social Sciences Cilt: 18 Sayı: 32 / Volume: 18 Issue: 32 
Özkan, Emel ve Funda Ünal (2009). Hisararkeoloji. Bursa: Rekmat Yayınları.

Özkul Fındık, Nurşen (2014). İznik Strlı Seramikleri Roma Tiyatrosu Kazısı (1980-1995). Ankara: Bilgin Kültür Sanat Yayınları.

Reynal Abadie, Catherine vd. Martz A. S., Cador, A., (2007). "Late Roman and Byzantine Pottery in Zeugma: Groups of the beginning of the 5.Century", Byzas 7 - Late Antique and Medieval Pottery and Tiles in Mediterranean Archaeological Contexts Bohlendorf-Arslan, Beate A.O. Uysal - J. Witte-Orr (eds.): İstanbul: Ege Yayınları, s.181-194.

Schaefer, Jörg (1968). Hellenistische Keramik aus Pergamon, Walter de Gruyter, Berlin.

Şahin, Reyhan (2014). "Karataş Burnu Yüzey Araştırmasında Bulunan Hellenistik ve Roma Dönemi Keramikleri”. Tüba-Ar 17: Ankara, Türkiye Bilimler Akademisi, 143-161.

(2017 baskıda). "Büyükorhan (Bursa) Yüzey Araştırmasında Ele Geçen Keramik Buluntuları". Uluslararası Mysia Olympos'u (Uludağ) Araştırmaları Çalıştayı, 8-11 Mayıs 2014.

Şenol, Ahmet Kaan (2003). Marmaris Müzesi Ticari Amphoraları. Ankara: DÖSIMM Basımevi.

Matbaacilik.

(2009). Taşucu Arslan Eyce Amphora Müzesi. İzmir: Taşeli

Uysal, A. Osman (2007). Demirköy Fatih Dökümhanesi Kazısı Seramik Buluntuları, Byzas 7 - Late Antique and Medieval Pottery and Tiles in Mediterranean Archaeological Contexts, Bohlendorf-Arslan, Beate A.O. Uysal - J. Witte-Orr (eds.), İstanbul: Ege Yayınları, s. 545-558.

Waksman, Sylvie Yona (2014). "Archaeometric Approaches to Ceramics Production and Imports in Medieval Cyprus". Cypriot Medieval Ceramics, Kıbrıs, Livadiotis, s. 257-277.

Uludağ Üniversitesi Fen-Edebiyat Fakültesi Sosyal Bilimler Dergisi Uludağ University Faculty of Arts and Sciences Journal of Social Sciences

Cilt: 18 Sayı: 32 / Volume: 18 Issue: 32 
http://www.anadoluselcuklumimarisi.com/selcuklular/selcuklu-elsanati/seramik-sanati [Erişim: 05.05. 2016]

http://www.explorewithmwnf.net/ [Erişim: 07.04.2016]

Uludağ Üniversitesi Fen-Edebiyat Fakültesi Sosyal Bilimler Dergisi Uludağ University Faculty of Arts and Sciences Journal of Social Sciences Cilt: 18 Sayı: 32 / Volume: 18 Issue: 32 